Był z pewnością osobą nieprzeciętną, ogarniętą pasją do historii. Wymagał wiele od siebie, ale na każdym kroku starał się zachęcać także i innych do sprostania wysokim standardom pracy naukowej. Obdarzony wiedzą i mądrością dzielił się nią chętnie, choć nie tylko w postaci pochwał, ale i krytyki - merytorycznej, często bardzo wyrozumiałej. Spoglądał na świat z dystansem, okiem dobrze poinformowanego optymisty, dostrzegając i z ironią komentując jego absurdy. Pozostanie po prof. Ciesielskim nie tylko Jego niezwykle bogaty, zróżnicowany i doceniany dorobek naukowy obejmujący kilkanaście monografii, wydawnictw źródłowych, dziesiątki studiów, artykułów i recenzji, ale także zapisany w pamięci wielu obraz znakomitego uczonego i pełnego empatii człowieka.

\title{
Historyk z powołania. Aleksander Ilin (1956-2020)
}

https://doi.org/10.19195/1429-4168.24.25

W listopadzie 2020 roku środowisko badaczy historii Europy Środkowo-Wschodniej poniosło ciężką stratę. Odszedł z tego grona Aleksander Ilin — znawca historii Białorusi i Ukrainy, a zwłaszcza znakomity badacz dziejów Polesia w XIX i XX wieku.

Urodził się na Ukrainie, w Wierchniedniprowsku. Ukończył Uniwersytet Dniepropietrowski, uzyskując wykształcenie matematyczne. Swoje życie związał Białorusią. W ostatnich latach pracował na Poleskim Uniwersytecie Państwowym w Pińsku. Karierę akademicką kontynuował w obszarze nauk ścisłych. Jego pasją przez ostatnich kilkadziesiąt lat była historia. Opublikował samodzielnie i we współautorstwie ponad 200 tekstów rozproszonych i około 10 książek. Wśród tych drugich były zarówno opracowania, jak i edycje tekstów źródłowych. Jego ustalenia dotyczące dziejów Pińszczyzny, tamtejszego ziemiaństwa, Kościoła prawosławnego, a wreszcie białoruskich, ukraińskich oraz polskich działaczy społecznych i politycznych, stały się ważnym elementem warsztatu dla historyków zarówno tego regionu, jak i ziem wschodnich dawnej, wielonarodowej Rzeczypospolitej. Wprowadził do obiegu czytelniczego i naukowego wiele materiałów źródłowych, pracowicie wyszukiwanych w archiwach polskich, białoruskich i ukraińskich. Książki dotyczące tak zwanego miejsca odosobnienia w Berezie Kartuskiej wejdą do kanonu historiografii poświęconej dziejom wewnętrznym Polski okresu międzywojennego. Ostatnia publikacja poświęcona temu zagadnieniu, wydana na Ukrainie wraz z Petro Mazurem - Narysy istorii Bereza-kartuskovo konctaboru (lypen 1934-veresen 1939), przyniosła zupełnie nowe ustalenia i wcześniej nieznane materiały źródłowe.

W ciągu ostatnich piętnastu lat miałem szczęście nie tylko współpracować zAleksandrem Ilinem, ale także niekiedy obserwować go w trakcie codziennej, żmudnej pracy historyka, prowadzonej przezeń czy to we wrocławskim Ossolineum, czy to - 
najczęściej — w Państwowym Archiwum Obwodu Brzeskiego. Jego zaangażowanie, sumienność, determinacja na polu kwerendy mogłyby być wzorem dla innych badaczy. Wykazywał nieczęsto spotykaną inwencję w określaniu zagadnień albo dotąd nierozpoznawanych, albo badanych fragmentarycznie czy powierzchownie. Nie wahał się wchodzić w spory naukowe. Zdawał sobie sprawę ze swego szczególnego położenia w środowisku historycznym, co wynikało z innego wykształcenia kierunkowego. Na łamach białorusko-ukraińskiego pisma „Sprawa” napisał w 2016 roku: „Może i dobrze, że nie mam wykształcenia historycznego, ponieważ sowiecka i postsowiecka nauka historyczna przesiąknięta jest kłamstwem, stereotypami, komunistycznym i szowinistycznym mitotwórstwem. Współczesna nauka historyczna potrzebuje świeżego spojrzenia pozbawionego uprzedzeń".

Aleksander Ilin zdawał sobie sprawę z roli współdziałania pomiędzy historykami. Wiele sygnowanych przezeń tekstów ma charakter współautorski, co najlepiej dowodzi jego zdolności do współpracy. Okazywał życzliwość, objawiającą się w postaci czy to propozycji wspólnych publikacji, czy to użyczania kopii archiwaliów, pozyskiwanych często kosztem dużych wyrzeczeń osobistych i materialnych. Niejednokrotnie udzielał wskazówek dotyczących poszukiwań źródłowych. Doświadczali tego także historycy, których nie miał okazji poznać osobiście.

Jego nieobecność będzie odczuwalna dla wielu z nas.

Piotr Cichoracki 